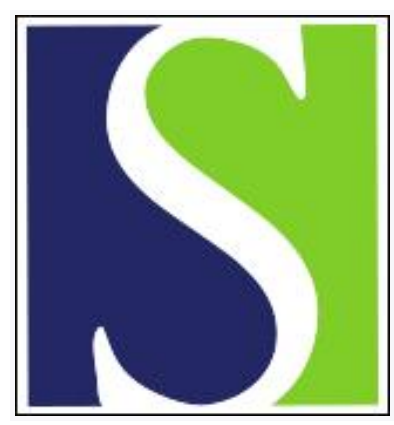

Scand J Work Environ Health 2008;34(4):239-249

https://doi.org/10.5271/sjweh.1266

Published online: 15 Sep 2008, Issue date: Aug 2008

Partial sick leave-review of its use, effects and feasibility in the Nordic countries

by Kausto J, Miranda H, Martimo K-P, Viikari-Juntura E

Affiliation: Finnish Institute of Occupational Health, Topeliuksenkatu 41 a A, Fl-00250 Helsinki, Finland. johanna.kausto@ttl.fi

The following articles refer to this text: 2010;36(5):404-412;

2010;36(6):515-516; 2012;38(2):134-143; 2013;39(1):37-45;

2015;41(3):219-221; 2017;43(5):447-456; 2019;45(2):203-208;

2023;49(1):23-32

Key terms: effect; feasibility; Nordic countries; partial sick leave; review; sickness absenteeism; sickness benefit; use; work disability

This article in PubMed: www.ncbi.nlm.nih.gov/pubmed/18815712 


\title{
Partial sick leave-review of its use, effects and feasibility in the Nordic countries
}

\author{
by Johanna Kausto, MSSc, ${ }^{1}$ Helena Miranda, DrMedSc, ${ }^{1}$ Kari-Pekka Martimo, MD, ${ }^{1}$ Eira Viikari-Juntura, \\ DrMedSc $^{1}$
}

\begin{abstract}
Kausto J, Miranda H, Martimo K-P, Viikari-Juntura E. Partial sick leave-review of its use, effects and feasibility in the Nordic countries. Scand J Work Environ Health 2008;34(4):239-249.

Partial sick leave and partial sickness benefits are currently available in Sweden, Norway, Denmark, and Finland. The literature was reviewed to determine their use, describe their recipients, find evidence of their effects, and explore attitudes towards and experiences with their use. Eight databases were searched. National sickness absence statistics and other relevant sources were also reviewed. Of the sickness benefits, partial benefits accounted for approximately one-fifth in Norway, less than $10 \%$ in Denmark, and over a third in Sweden. In Finland, partial sick leave was seldom used during the first year (2007) of benefit availability. Few peer-reviewed studies on its effects were identified, and scientific evidence was scarce. Its acceptance was good in all four countries. Most of the recipients were women and over 45 years of age. Studies of its feasibility seem congruent in reporting hindrances due to inflexible work arrangements and poor collaboration between actors. More research and more rigorous study designs are needed to determine whether partial sick leave is feasible and beneficial in keeping those with reduced work ability in worklife.
\end{abstract}

Key terms sickness absenteeism; sickness benefit; work disability.

The Nordic countries are all facing somewhat similar challenges in public health, one of the most significant problems being a high rate of sickness absence and inflow into sickness benefits. This phenomenon has been particularly strong in Sweden and Norway since the end of the 1990s, although some slowing in the trend has been documented lately. Denmark and Finland, in which the level of sickness absence has traditionally been lower and more stable than in Sweden and Norway, have also experienced growing sickness absence in recent years. Until lately, a characteristic feature in Sweden and Norway has been an inverse association between unemployment and sickness absence $(1,2)$. In general, attaining and retaining a high employment rate is crucial for the Nordic countries, all of which are dealing with an aging population $(3,4)$.

In line with the general trend in other countries in the Organization for Economic Co-operation and Development (OECD) (5), employment policies in Sweden, Norway, and Denmark have focused on activating employees with reduced work ability and supporting them in continuing and returning to work. The means for reducing long-term sickness absence differ to some extent in the Nordic countries due structural differences and the variation in sickness policies $(6,7)$ (appendix I). Partial sick leave has been offered as an option that enables a person to flexibly combine work with sickness benefits (6-8). It involves working part-time or, alternatively, full-time hours but performing modified tasks or ordinary tasks with reduced input, and receiving a partial sickness benefit on top of a partial salary. The authorities have strongly promoted its use, perhaps the most strongly in Sweden, with the recommendations of partial sick leave as the primary choice, if sick leave is needed. In Finland, the use of a partial sickness benefit was not introduced until in 2007, and it had stricter terms than in the other three countries (table 1).

Compared with complete absence from work, partial sick leave is assumed to have positive effects on health and well-being, and it is believed to facilitate the return to full-time work. At the same time, scientific evidence on the effects of sick leave, in general, is so far scarce (9). There is some indication of long-term sick leave or a high rate of sickness absence being a risk factor for disability pensioning and the termination of employment followed by unemployment (10-13). Sickness absence

Correspondence to: Johanna Kausto, Finnish Institute of Occupational Health, Topeliuksenkatu 41 a A, FI-00250 Helsinki, Finland. [E-mail: johanna.kausto@ttl.fi] 
Table 1. Partial sickness benefits in Nordic countries.

\begin{tabular}{|c|c|c|c|c|}
\hline & Sweden & Norway & Denmark & Finland \\
\hline Eligibility & $\begin{array}{l}\text { Work ability reduced to } 75 \% \text {, } \\
50 \% \text { or } 25 \% \text { of full ability }\end{array}$ & $\begin{array}{l}\text { Work ability reduced by at least } 20 \% \text {; work- } \\
\text { hours or workpace reduced accordingly }\end{array}$ & $\begin{array}{l}\text { Reduction in workhours by at } \\
\text { least } 4 \text { hours per week }\end{array}$ & $\begin{array}{l}\text { Reduction in workhours } \\
\text { and salary to } 40-60 \% \\
\text { of the regular hours and } \\
\text { salary }\end{array}$ \\
\hline $\begin{array}{l}\text { Partial benefit } \\
\text { available }\end{array}$ & From 1st sickness benefit day & From 1st sickness benefit day & From 1st sickness benefit day & $\begin{array}{l}\text { After } 60 \text { days of full } \\
\text { sickness benefit }\end{array}$ \\
\hline $\begin{array}{l}\text { Amount of } \\
\text { benefit }\end{array}$ & $\begin{array}{l}25 \%, 50 \% \text { or } 75 \% \text { of full sick- } \\
\text { ness benefit }\end{array}$ & According to the reduction in work ability & $\begin{array}{l}\text { According to the reduction in } \\
\text { workhours }\end{array}$ & $\begin{array}{l}50 \% \text { of the preceding } \\
\text { full sickness benefit }\end{array}$ \\
\hline \multirow[t]{2}{*}{$\begin{array}{l}\text { Length of } \\
\text { payment }\end{array}$} & $\begin{array}{l}364 \text { days in } 15 \text { months (in- } \\
\text { cluded in the maximum length } \\
\text { of the payment for full sickness } \\
\text { benefit) }\end{array}$ & $\begin{array}{l}52 \text { weeks (in } 3 \text { years) (included in the maxi- } \\
\text { mum length of payment for full sickness } \\
\text { benefit) }\end{array}$ & $\begin{array}{l}52 \text { weeks in } 18 \text { months (in- } \\
\text { cluded in the maximum length } \\
\text { of payment for full sickness } \\
\text { benefit) }\end{array}$ & $\begin{array}{l}12-72 \text { weekdays (not in } \\
\text { cluded in the maximum } \\
\text { length of payment for } \\
\text { full sickness benefit) }\end{array}$ \\
\hline & & $\begin{array}{l}\text { Active sick leave-return to work to modi- } \\
\text { fied duties (maximum of } 8 \text { weeks, } 100 \% \text { of } \\
\text { regular salary paid by the National Insurance } \\
\text { Administration) }\end{array}$ & & \\
\hline
\end{tabular}

has also been shown to predict mortaility $(14,15)$, but its role has been suggested to be more of a global indicator of health.

Since partial sick leave is now available in all four countries, it is important to look at its use and feasibility. In addition, there is a need to evaluate existing evidence on the effects of partial sick leave. The results of these studies should be considered in the contexts of the social security systems in the countries in which the studies are performed. We restricted our review to Denmark, Finland, Norway, and Sweden. These four Nordic countries are relatively similar in regard to social security systems and statistics on sickness absence and available benefits. Previously, no reviews have been conducted on the subject. This review addresses the following questions: (i) to what extent are partial sick leave and partial sickness benefit used and who are the recipients of partial sickness benefit in the four Nordic countries, (ii) what is known about the effects of partial sick leave at the individual and group level, and (iii) what are the attitudes towards partial sick leave and experiences with its use (feasibility)?

\section{Material and methods}

In order to investigate the use of partial sick leave, we scrutinized statistics from national reports. In addition, we contacted the Swedish and Norwegian social insurance institutions for numeral data. To explore the second and third study questions, we carried out a systematic search of the literature in Google Scholar, PubMed, Embase, PsycINFO, Business Source Premier, EconPapers, ProQuest, and Social Services Abstracts up until April 2008. We used the following key words, MESH terms, and keyword strings: "Partial sick leave", "Part time sick leave", "Partial sick listing", "Partial sickness absence", Absenteeism [MESH] OR Sick leave
[MESH] AND "Part time" OR "Partial", "Effect(s) OR outcome(s) OR consequence(s) of sick leave", "Partial sickness benefit(s)", "Partial sickness allowance(s)", and "Partial sickness compensation". In addition, we searched Google Scholar for the following Swedish terms: "partiell sjukskrivning" (partial sick leave) and "deltidssjukskrivning" (part-time sick leave). As it became evident during the literature search that only a few peer-reviewed studies have been conducted on the subject, we also decided to include nonpeer-reviewed study reports and textbook chapters in the search. In addition to the databases, we examined personal archives and consulted the literature cited in the references.

In all, the literature search yielded over a thousand titles. We reviewed all of the abstracts and retrieved relevant sources. Studies that addressed any effects of partial sick leave at the level of groups or individuals (prospective studies) or attitudes towards partial sick leave or experiences with its use (any study design) were considered as relevant. We included English, Swedish, Finnish, Norwegian, and Danish sources that reported original data from all types of studies conducted in the Nordic countries. Preliminary searches suggested that there would be too few articles reporting methods in sufficient detail to allow quality assessment. Therefore, a systematic review was not feasible.

\section{Results}

\section{Utilization of partial sick leave and recipients of a partial sickness benefit}

Sweden. The proportion of all the sickness benefits that are partial has been rising in Sweden. In 2006, the percentage of partial benefit days was 36\% (39\% for women and $32 \%$ for men) (table 2), and $68 \%$ of the partial sickness benefit days were granted to women. Partial benefits the most often accounted for $50 \%$ of the full 
benefits. In 2006, $57 \%$ of the paid partial sickness benefit days belonged to this category (Unpublished data: Försäkringskassan. Datalagret STORE. Försäkringskassan, Statistikenheten; 2007).

The distribution of compensated partial sickness benefit days in different age groups is shown in figure 1 . In 2006, people from 55 to 70 years of age formed the largest group, receiving a third of the compensated partial sickness benefit days (Unpublished data: Försäkringskassan. Datalagret STORE. Försäkringskassan, Statistikenheten; 2007). In Sweden, a partial sickness benefit is more frequently used after a period of full benefit than from the very beginning of a person's sick leave. A partial sickness benefit is especially common among women who have been sick-listed for longer than a year. In a study among 1800 patients sick-listed for back, neck, or shoulder complaints for at least 4 weeks (17), the shift from full to partial sick leave took place an average of 4 months from the beginning of the sick leave.

Five Swedish studies (17-21) reported the characteristics of the people on partial sick leave. Eklund et al (18) investigated a random sample of 4844 persons on full or partial sick leave for at least 2 weeks in 2002. The study especially focused on the 989 persons who had been on partial sick leave from the beginning of their absence. Eighty percent of them were women. Altogether $15 \%$ of the women and $7 \%$ of the men in the total sample were on partial sick leave. The results showed that especially working in the public sector, having a high income level, working daytime, and having musculoskeletal disorders, complications during pregnancy, or long-term (over 60 days) sickness absences during the past 5 years increased the odds of being on partial sick leave. Those who were partially sick-listed more often reported poor perceived health and a high workload preceding their sick leave. They also expected to not to return to work and to move to partial disability pension more often than those on full sick leave. The authors indicated that partial sickness benefits seem to
Table 2. Proportion of partial sick leaves or sickness benefits of all eligible sick leaves or sickness benefits.

\begin{tabular}{lcccc}
\hline & $\begin{array}{c}\text { Sweden } \\
(\%)\end{array}$ & $\begin{array}{c}\text { Norway } \\
(\%)\end{array}$ & $\begin{array}{c}\text { Denmarkc } \\
(\%)\end{array}$ & $\begin{array}{c}\text { Finland } \\
(\%)\end{array}$ \\
\cline { 2 - 5 } Men & 31.6 & 13.3 & 7.4 & - \\
Women & 39.1 & 21.1 & 9.2 & - \\
\hline All & 36.3 & 18.0 & 8.4 & 2.9 \\
\hline
\end{tabular}

a Sickness benefit days in 2006 (Unpublished data: Försäkringskassan Datalagret STORE. Försäkringskassan, Statistikenheten; 2007).

b Medically certified sick leaves, the first quarter of 2006 (22).

c Sickness benefits, the first quarter of 2006 (24).

d Sickness benefit days in 2007 (16)

be used in connection with long-lasting and complicated health problems.

Renstig \& Sandmark (19) reported findings from a survey among 231 women on long-term (either partial or full) sick leave in 2003 and 2004. In line with the results of Eklund et al (18) the findings showed that being on partial sick leave was associated with a higher education. Bergendorff et al (17) reported that partial sick leave was the most common among men aged 35 to 44 years and women aged 25 to 34 or 45 to 54 years. Both those with higher education and those in office work or customer services were on partial sick leave more often than the others. In a random sample of 364 persons on partial sick leave, Annerblom \& Sjöström (21) found that 80\% were women, and most of them were married or cohabiting and worked in the public sector in a full-time job before their sick leave. Musculoskeletal disorders and stress or burnout were the most common causes of the partial sick-listing. In a cross-sectional survey among 770 persons on sick leave, Sieurin et al (20) found that being on partial sick leave was not particularly strongly associated with occupation, diagnosis, or age.

Norway. The proportion of partial sick leaves among all medically certified sick leaves in Norway increased from $12 \%$ in the beginning of 2003 to $18 \%$ at the end of the first quarter of 2006 (21\% for women and $13 \%$ for men)

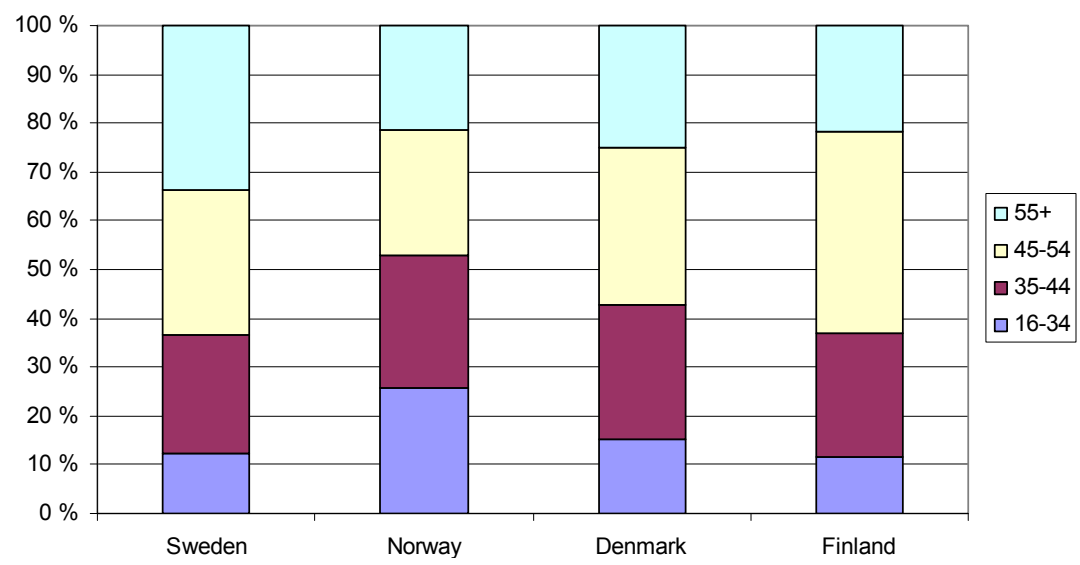

Figure 1. Partial sick leaves or partial sickness benefits by age. [Sweden - total number of partial sickness benefit days, year 2006 (Unpublished data: Försäkringskassan. Datalagret STORE. Försäkringskassan, Statistikenheten; 2007)); Norway-total number of medically certified partial sick leaves, the first quarter of 2007 (22); Denmark-total number of partial sickness benefits, year 2006 (24); Finland - total number of partial sickness benefits granted in January-June, 2007 (26)] 
(22). In the beginning of $2007,71 \%$ of the total number of partial sick leaves were granted to women. One-third of all of the recipients worked in social and health care, $15 \%$ in commerce or the hotel and restaurant industry and $12 \%$ in education [Unpublished statistics: NAV-statistics. 2007 (obtained from The Norwegian Labour and Welfare Administration (NAV) via personal contact)]. People on partial sick leave seem to be distributed more evenly across the age groups in Norway than in the other countries (figure 1).

Denmark. The use of a partial sickness benefit has increased in recent years in Denmark $(23,24)$. In the beginning of 2006, $8 \%$ of all the sickness benefits were partial (24). The proportion was, however, approximately $19 \%$ if sickness benefit episodes lasting less than 8 weeks are not included (25). In 2006, 60\% of the receivers of a partial sickness benefit were women, and a third of them were 45 to 54 years of age (figure 1). The proportion of partial sickness benefits of all sickness benefits was higher in the older age groups, and it increased with age for both genders (24). A total of $13 \%$ of the receivers worked in administrative and office work, and $8 \%$ were employed in education and research (23).

No register-based information on the causes of sickness absence is available. Results based on a survey conducted in 2007 indicate that there are no significant differences in the use of partial sick leave across different causes of sick leave (23). As in Sweden, a partial sickness benefit in Denmark is commonly used after full benefits. Receivers of sickness benefits were classified by the authorities according to the risk of losing contact with the labor market (appendix I). In 2006, a partial sickness benefit was the most frequently used by those who were expected to return to work soon (the proportion of partial sickness benefits of all the benefits being $26 \%$ in this group). Those who had a risk of long-term illness and not returning to work used partial sickness benefits more rarely (the proportion being 13\%) (24). This finding seems to be partly contradictory to the results of the Swedish study (18).

Finland. Partial sick leave was introduced in Finland in 2007 with more strict terms than in the other Nordic countries. Thus the available information on the use of this benefit is still limited. People who have received a full sickness allowance for at least 60 days are eligible for a partial sickness benefit. The proportion of partial sickness benefits of all eligible sickness absences was roughly 3\% during the first year. Of the receivers, $70 \%$ were women, and around $40 \%$ were 45 to 54 years of age (figure 1). The most common causes for partial sicklisting were mental problems (38\%) and musculoskeletal disorders (35\%). A total of $27 \%$ of the receivers worked in social and health care, $16 \%$ were in administrative and office work, and $15 \%$ did work in industry, mining, or construction (26).

\section{Effects of partial sick leave}

We identified six prospective studies that reported original data on the effects of partial sick leave from the Nordic countries (table 3). The results of a Swedish study (17) proposed that patients on full sick leave generally returned to work sooner than those who shifted from full to partial sick leave at some point of the sickness absence. However, after 2 years, a slightly larger proportion of those who had returned to work directly from partial sick leave was fully recovered and had had fewer recurrent sick leaves within 1 year than those who had been on full sick leave for the whole absence period or those who had shifted back to full sick leave before returning to work. In line with these results, two other Swedish studies $(18,27)$ found the odds of returning to work to be lower for those who had been on partial sick leave from the beginning of the sickness absence than for those on full sick leave.

Findings from a Norwegian cluster-randomized controlled trial (28) indicated that increased use of so-called active sick leave (return to work to modified duties) did not affect the average number of days on sick leave, long-term disability, or quality of life. The results may, however, be partly explained by the minor use of active sick leave among the intervention groups. A nonrandomized comparison of people on active sick leave and full sick leave in the same study proposed that those who had been on active sick leave were more likely to return to work earlier than those on ordinary sick leave. Another Norwegian study (29), investigating physicians' sick-listing practices, reported that their increased use of partial sick leave had no effect on patients' return to work, recurrence of sick leave, or use of disability benefits. A Swedish study (30) reported that vocational rehabilitation was more successful for those who had been on partial sick leave before the rehabilitation than for those on full sick leave. A recent report from Denmark (23) showed that, after the 13th week of sick leave, the odds of returning to work were higher for those on partial sick leave. Furthermore, in 2006, $15 \%$ of those on partial sick leave, compared with $25 \%$ of those on full sick leave, were still sick-listed a year after the beginning of the sick leave (the study has not been included in table 3 due to insufficient reporting of the study design and methods).

\section{Attitudes towards partial sick leave and experiences from its implementation}

Twelve studies were identified that reported original data either on attitudes towards partial sick leave or 
Table 3. Studies on the effects of partial sick leave at the level of groups or individual patients.

\begin{tabular}{|c|c|c|c|c|}
\hline Study & Country & Study population & Study design & Outcomes \\
\hline $\begin{array}{l}\text { Bergendorff } \\
\text { et al, } 1997 \\
\text { (17) }\end{array}$ & Sweden & $\begin{array}{l}1800 \text { patients sick-listed for } \\
\text { back or neck complaints for } \\
\text { at least } 4 \text { weeks }\end{array}$ & $\begin{array}{l}\text { Prospective register- } \\
\text { based study, follow-up } \\
\text { period of } 2 \text { years }\end{array}$ & Time to return to work \\
\hline
\end{tabular}

Results

$\begin{array}{ll}\begin{array}{l}\text { Bergendorff Sweden } \\ \text { et al, } 1997\end{array} & \text { back or neck complaints for }\end{array}$

Patients who had been on full sick leave returned to work on the average sooner than those who shifted from full to partial sick leave during the sickness absence before return to work; at 2 years $90 \%$ of the patients in the latter group were fully recovered (versus $84 \%$ of the employees in the former group and $59 \%$ of those who shifted back from partial to full sick leave before return to work)

Marnetoft Sweden 732 persons on long-term Prospective register- Successful vocational et al, $2001 \quad$ sick leave ( $\geq 90$ days, begin- based study, follow-up rehabilitation (no ning in 1992, 1993 or 1994) period of 24 months who had undergone vocational rehabilitation during the sickness period

Sheel et al, Norway 663 persons on active sick $2002(28)$ leave and 1995 persons on ordinary sick leave for $>12$ weeks were higher for those who had been partially sickeconomical benefit or listed before the vocational rehabilitation program lowered benefit level than for those who had been on full sick leave at the follow-up)

Nonrandomized regis- Days off work, return ter-based comparison to work of the two groups, follow-up period of 1 year 65 municipalities Cluster-randomized controlled trial, followup period of 1 year

Average number of days on sick leave, long-term disability quality of life

Eklund et Sweden 4844 persons on either full al, $2004 \quad$ or partial sick leave for at least 15 days

Prospective registerbased survey, followSick leave duration up period of 1.5 years

Lidwall, Sweden 12361 persons beginning

$2006(27)$ either partial or full sick leave (lasting for at least 60 days) in 1999, 2001 or 2003

Kann \& Norway 2779 physicians

Brage, Prospective registerbased study, follow-up period of 13 months

Persons on active sick leave returned to work before 50 weeks more often than those on ordinary sick leave

Increased use of active sick leave in a municipality had no effect on the average number of days on sick leave, long-term disability or quality of life

Being partially sick-listed from the beginning of the sickness absence was associated with longer sickness absence periods (especially among men)

Time to return to work The odds of returning to work were lower for those who had been on partial sick leave from the beginning of the sick leave than for those on full sick leave

Prospective register- Patients' return to based study, follow-up work, recurrence of period of up to 1.5 sick leave and use of Physicians' increased use of partial sick leave did not affect the outcome measures 
Table 4. Continued.

\begin{tabular}{lll}
\hline Study & Country & Study population \\
& \\
\hline van der & Sweden & 587 managers and trade \\
Capellen, & union representatives \\
$2004(32)$ & at workplaces, 203 and \\
& 252 employees at the \\
& offices of the Swedish \\
& Social Insurance Agency \\
& (Försäkringskassan) and \\
& Employment Agency, 1754 \\
& persons either working or \\
& on partial or full sick leave \\
& and 548 physicians
\end{tabular}
$\begin{array}{ll}\text { Study design } & \begin{array}{l}\text { Outcomes or inter- } \\ \text { ests of the study }\end{array}\end{array}$

Telephone Attitudes towards parinter- tial sick leave, barriers views and encountered in using cross- partial sick leave sectional survey (physicians)

$87 \%$ of the human resource managers, $90 \%$ of the trade union representatives, $97 \%$ of the employees at the offices of the Swedish Social Insurance Agency, and $74 \%$ of the persons interviewed believed partial sick leave to lead to shorter sickness absences; respectively, 73\%, 93\%, 92\% and 63\% believed it was difficult to return to work straight from full sick leave; the physicians (particularly psychiatrists) were the least positive; the priority of partial sick leave compared with full sick leave was questioned more often; the most-often reported drawbacks in implementing partial sick leave were the physicians' minor use of partial sick-listing, difficulties with work arrangements (due to collective agreements), and few opportunities to modify workhours.

Renstig \& Sweden 231 women on partial or Sandmark, full sick leave for at least 2005 (19) 90 days (cases) and 194 controls

Eklund \& Sweden Baseline: a random sample Ossowicki, of 6171 persons on sickleave, sick-listed for at least 15 days; follow-up: 5136 respondents

Case- Risk factors of long-

control term sickness absence

survey among women

Register- Extent to which per-

based sons on sick-leave 2005 (33)

pro-

survey,

follow-up

period of

1 year

Vuorinen Finland 118 employer representa-

et al, 2007 tives and 210 employees

(34)

Open

Extent to which partial

sick leave is found feasible and is believed to benefit return to work and prevent disability

Kann \& Norway 2244 physicians

Brage, 2007

(29)

Cross- Attitudes towards and

sectional implementation of new

survey regulations on sickness insurance (aiming at, for example, increased use of partial and ASL)

Damgaard Den- 5 municipal administrators, SemiEvaluation of the imple\& Boll, 2007 mark (25)

14 people in aging sickness benefit cases interviews in the municipalities, 18 physicians and 17 employers in five municipalities.

Arrelöv, Sweden 2416 physicians

2007 (35)

Varonen Finland 295 physicians et al, 2007 (36)

Sieurin et al, Sweden 770 persons who had been 2007 (20) on sick leave for more than 28 days

Crosssectional survey

Crosssectional survey mentation of amendments to the law on sickness benefits that were passed approximately a year earlier in 2005

More than $50 \%$ of the women on long-term sick leave (especially those with higher education) were willing to return to work if their workhours were reduced

Approximately $60 \%$ (especially those sick-listed for less than 60 days, with higher education or reporting good perceived health) reported that they would be able to work at least part of their workhours if they had better control over their work arrangements; $32 \%$ (especially women) reported that they would like to work part-time (and move to partial sick leave)

$76 \%$ of the employer representatives and $87 \%$ of the employees believed that partial sick leave was beneficial to return to work; $73 \%$ and $81 \%$, respectively, found it to prevent permanent disability; and $32 \%$ and $46 \%$ of the respondents found the measure feasible

$72 \%$ reported a more frequent use of partial sick leave; they believed an increased use of partial sick leave would keep patients integrated in worklife and would reduce the probability of disability pensioning

Different actors have positive views on the measure, most of the barriers to the use of partial sick leave were found with other partakers, for example, physicians hoped for tighter and better quality collaboration with municipalities and found the employers, in some cases, to be reluctant towards employees' return to part-time work; employers found that physicians did not use the measure sufficiently and that the instructions given about modifying worktasks were often inadequate

Physicians' views on $58 \%$ of the physicians found that partial sick leave should be used more

ening sick leaves and avoiding sick-listing

Internet Extent to which physisurvey cians are prepared to implement partial sicklisting and factors that are seen as promoting or preventing the use of the measure

The respondents' views $92 \%$ of those on partial sick leave, $63 \%$ of those on full sick

$58 \%$ found introducing the benefit in Finland important, and $49 \%$ believed that they could use the measure among their patients; barriers to the use of partial sick-listing were mostly found in the difficulties in reducing the workhours and workload of patients and finding substitutes for only part of the workday leave, and $62 \%$ of those who had returned to work believed that the arrangement, all in all, was or would be profitable for them as individuals; however, those on partial sick leave also believed that the arrangement had negative consequences for their career and salary, as well as affected negatively colleagues, superiors, and the whole organization; $30 \%$ of those on partial sick leave and $<20 \%$ of those on full sick leave believed that they would return to full-time work within a year experiences from its use in the Nordic countries (table 4). Surveys, interviews, a dialogue conference, and a randomized controlled intervention study have been conducted among individual patients (19-21, 31-33), employees $(31,32,34)$, employers $(25,31,32,34)$, physicians $(25,29,31,32,35,36)$, trade union representatives (32), and personnel in social insurance and employment agencies $(31,32)$, as well as in municipalities 
$(25,37)$. The results indicated mainly positive attitudes towards partial sick leave. The different actors found partial sick leave to be beneficial in enhancing return to work. The priority of partial sick leave, as compared with full sick leave in sick-listing, was, however, questioned to some extent by all of the other actors, except the representatives of the Swedish Social Insurance Agency (32). A Norwegian study (31) found that the patients on full sick leave were interested in trying active sick leave, if offered the opportunity. In line with the Norwegian study, two Swedish studies $(19,33)$ among people on full sick leave reported that especially women and those sick-listed less than 60 days or with higher education, a demanding job, or good perceived health were interested in partial sick leave. They believed they were able to work part-time if provided control over the worktasks, pace of the work, and workhours.

Barriers to the use of partial sick leave have been reported as well. Scheel et al (31) found that the lack of information and time, as well as poor communication and collaboration between employers, physicians, and local insurance authorities, were the main obstacles to the use of active sick leave in Norway. Recent results from Denmark (25) indicated that physicians hoped for better collaboration with municipalities. They considered the employers sometimes to be reluctant towards employees' return to part-time work, possibly due to inflexible work arrangements. Employers reported that physicians did not use partial sick leave sufficiently, and their instructions to modify the worktasks of employees returning to work were often inadequate. Findings from a Finnish survey (36) suggested that physicians found the main difficulties to be connected with reducing workhours and the physical and mental workload of the patients. Finding substitutes for only part of the workday was also reported to be an obstacle for the use of partial sick leave.

Two community interventions, designed to promote the implementation of active sick leave, were carried out in Norway (37). Targeting the barriers identified earlier (31) was not enough to increase the use of active sick leave. A proactive approach, including a personal follow-up of patients, was found to be more effective.

\section{Discussion}

The use of partial sick leave seems to be growing in the Nordic countries. So far, it has been used mostly in relation to returning to work after full-time sick leave. The receivers of such benefits have predominantly been women in, for example, social and health care, office work, and education. The users of partial sick leave have primarily been older employees. Other factors related to being on partial sick leave have been work in the public sector, high income level, daytime work, musculoskeletal disorder as the cause of sick leave, and prior long-term sickness absence. Some conclusions on the use of partial sick leave were, however, hampered by contradictory data.

A review of the literature suggested that most employees, employers, and physicians find partial sick leave important and beneficial. The measure is expected to have beneficial effects in keeping those with reduced work ability integrated in worklife. In the implementation of the measure, the difficulties that have been reported are primarily related to practical issues, for example, problems with work arrangements, relatively inflexible collective agreements, or poor collaboration between the partakers. It has been emphasized that, in order to enhance the use of partial sick leave, the solutions suggested to workplaces need to be practical. There is some indication that a substantial proportion of employees on full sick leave is willing to move to partial sick leave if provided control over the work arrangements. The types of work or lines of business suited for such a measure are still unclear.

In addition to the ability of employers to provide flexible work arrangements, physicians' practices in prescribing sick leave affect the use and application of partial sick leave. Scientific evidence on sick-listing practices is scarce. Thus many questions related to the use of partial sick leave also remain unanswered. Some evidence exists on the problems physicians encounter with sick-listing, mainly in association with conflicting roles of physicians, a lack of knowledge about legislation, and prospects of collaboration with other authorities (38). One study (39) reported that occupational physicians prescribed partial sick leave more often than other physicians did. Later studies $(40,41)$ also indicate that physicians find assessing work ability and the length and degree of absence problematic. There is some evidence of a deficient quality of medical certificates $(38,42)$. It is possible that certificates that lack information about the possibility of partial sick leave, patient's current work, and the prognosis of returning to work, misinform those who make decisions about sickness benefits and affect other measures taken in relation to the return to the work process.

Contrary to expectations, most of the reviewed studies imply that being on partial sick leave does not necessarily enhance return to work. However, the results are partly contradictory, and the scientific evidence is not yet sufficient, either in terms of the quantity or quality of the studies. It is likely that employees on partial sick leave differ from those on full sick leave (18). The selection may depend on various country-specific features, such as other alternative social security benefits or employment policies. This possibility may partly explain the 
conflicting results from different Nordic countries. It has been discussed whether the availability of partial sickness benefits invites new recipients who possibly use the benefits for other than health-related problems and, furthermore, that the use of partial benefits should be, at least in Sweden, carefully administered to prevent an increase in the total use of sickness benefits (43). Partial healthrelated benefits, which add more flexibility to the income security system, have been suggested however to possibly have a positive effect on the employment rate (8).

The selection of persons into to different types of benefits makes research of their effects difficult. It is ethically problematic to carry out a randomized study to compare two existing types of benefits, for example, partial and full sick leave. The only randomized study carried out so far looked at whether an enhancement of the use of so-called active sick leave in municipalities affected the length of sick leave and disability (28). An on-going study (44) is assessing the effects of early part-time sick leave in Finland, where the statutory benefit so far is available only after a longer period of full sick leave.

Finally, all the actors seem to agree on the importance of partial sick leave in supporting employees in continuing and returning to work. Efforts have been made to remove the practical hindrances to the use of the measure. Nevertheless, the expected results are not always achieved. The interests, concerns, and incentives of the different partakers in the return-to-work process differ, or are even conflicting, and thus may explain the lack of commitment and consequent failures (45). It is necessary to realize that these problems exist, as well as to take the national contexts with diverse policies and structures $(7,45)$ into account, when research on and the implementation of partial sick leave is advanced.

In conclusion, the use of partial sick leave has, in general, increased during recent years, but it varies widely in the four Nordic countries covered in this review. Attitudes towards partial sick leave are mainly positive. Poor collaboration between the actors and inflexible work arrangements have been regarded as hindrances to the use of partial sick leave. More research and more rigorous study designs are needed before it can be determined whether partial sick leave is a feasible and beneficial measure in keeping those with reduced work ability integrated in worklife. There is a general need to improve and harmonize the sickness absence data in Nordic countries to better enable a follow-up of trends and the effects of policy changes.

\section{Acknowledgments}

We would like to thank Ola Rylander in Försäkringskassan, Sweden, and Ola Thyne in NAV, Norway, for providing statistics on sickness benefits and sick leaves in Sweden and Norway, respectively.

\section{References}

1. Askildsen JE, Bratberg E, Nilsen OA. Unemployment, labor force composition and sickness absence: a panel data study. Health Econ. 2005;14:1087-101.

2. Hesselius P. Does sickness absence increase the risk of unemployment? J Socio-Economics. 2007;36:288-310.

3. Virjo I. Employment rate potential in the Nordic countries: an overview [Internet]. Copenhagen: Nordic Council of Ministers. TemaNord, 569 [cited 9 June 2008]. Available at: http://www. norden.org/pub/velfaerd/arbetsmarknad/sk/TN2006569.pdf.

4. Andersen TM. The Scandinavian model-prospects and challenges. Int Tax Public Financ. 2008;15:45-66.

5. Organization for Economic Co-operation and Development (OECD). New ways of addressing partial work capacity: OECD thematic review on sickness, disability and work [issues paper and progress report] [Internet]. Paris: OECD; 2007 [cited 9 June 2008]. Available at: http://www.oecd.org/dataoecd/6/6/38509814.pdf.

6. Försäkringskassan. Nordiska strategier för att begränsa sjukfrånvaron [Strategies of the Nordic countries for limiting sickness absence] [Internet]. Försäkringskassan; 2008. Socialförsäkringsrapport, 1 [cited 9 June 2008]. Available at: http://www.forsakringskassan.se/filer/publikationer/pdf/ sfr0801.pdf.

7. Hytti H. Disability policies and employment: Finland compared with the other Nordic countries [Internet]. Helsinki: The Social Insurance Institution of Finland, Research Department; 2008 [cited 10 June 2008]. Social Security and Health Research: Working Papers, 62. Available at: http://www.kela. fi/in/internet/liite.nsf/NET/280508093718EK/\$File/Selosteita62.pdf?openElement.

8. Hytti H. The Finnish employment and income security models in a Nordic comparison [Internet]. Helsinki: Social Insurance Institution of Finland, Research Department; 2006 [cited 9 June 2008]. Social Security and Health Research Working papers, 52. Available at: http://www.kela.fi/in/internet/liite.nsf/NET/100506142717EK/\$File/Seloste52netti. pdf?OpenElement.

9. Vingård E, Alexanderson K, Norlund A. Consequences of being on sick leave. Scand J Public Health. 2004;32(suppl 63):207-15.

10. Kivimäki M, Forma P, Wikström J, Halmeenmäki T, Pentti J, Elovainio M, et al. Sickness absence as a risk marker of future disability pension: the 10-town study. J Epidemiol Community Health. 2004;58:710-11.

11. Alexanderson KAE, Borg KE, Hensing GKE. Sickness absence with low-back, shoulder, or neck diagnoses: an 11-year follow-up regarding gender differences in sickness absence and disability pension. Work. 2005;25:115-24.

12. Lund T, Kivimäki M, Labriola M, Villadsen E, Christensen KB. Using administrative sickness absence data as a risk marker of future disability pension: the prospective DREAM study of Danish private sector employees. Occup Environ Med. 2008;65(1):28-31.

13. Virtanen M, Kivimäki M, Vahtera J, Elovainio M, Sund R, Virtanen P, et al. Sickness absence as a risk factor for job termination, unemployment, and disability pension among 
temporary and permanent employees. Occup Environ Med. 2006;63:212-17.

14. Kivimäki M, Head J, Ferrie JE, Shipley MJ, Vahtera J, Marmot MG. Sickness absence as a global measure of health: evidence from mortality in the Whitehall II prosopective cohort study. BMJ. 2003;327:364

15. Vahtera J, Pentti J, Kivimäki M. Sickness absence as a predictor of mortality among male and female employees. J Epidemiol Community Health. 2004;58:321-6.

16. The Social Insurance Institution of Finland. Verkkotilastot: aikasarjat, vuosi/neljännes: 14.8.2008. [Time series: year/ quarter of year: 14 August 2008] [Internet]. Helsinki: Social Insurance Institution of Finland [cited 1 September 2008]. Available at: http://www.kela.fi/it/kelasto/kelasto.nsf/NET/ 040603120122MV/\$File/02_Sairvak.pdf?OpenElement.

17. Bergendorff S, Hansson E, HanssonT, Palmer E, Westin M, Zetterberg C. Projektbeskrivning \& undersökningsgrupp: rygg och nacke 1 [Project description \& study group: back and neck 1]. In: Partiell sjukskrivning-förekomst och utfall [Partial sick leave-occurrence and outcome]. Stockholm: Riksförsäkringsverket; 2001 [cited 9 June 2008]. RFV redovisar, 4. Available at: http://www.fk.se/filer/publikationer/pdf/red0104. pdf.

18. Eklund M, von Granitz H, Marklund S. Deltidssjukskrivningindivid, arbetsplats och hälsa [Partial sick leave-individual, workplace and health]. In: Hogstedt C, Bjurvald M, Marklund S, Palmer E, Theorell T, editors. Den höga sjukfrånvaron—sanning och konsekvens [The high sickness absence rate-evidence and consequences]. Stockholm: Statens Folkhälsoinstitut; 2004. p 83-121.

19. Renstig M, Sandmark H. Kvinnors sjukskrivning: en studie om riskfaktorer för långtidssjukskrivning [Womens's sickness absence: a study of risk factors for longterm sickness absence]. Stockholm: Karolinska Institutet, Institutionen för Folkhälsovetenskap, avdelningen för yrkesmedicin och Women's Business Research Institute; 2005.

20. Sieurin L, Josephson M, Vingård E. Partiell eller hel sjukskrivning, konsekvenser för individen: delrapport 1; Redovisning av deskriptiv data [Partial or full sick leave, consequences for the individual: report no 1; report and descriptive data]. Uppsala (Sweden): Akademiska Sjukhuset, Uppsala Universitet; 2007.

21. Annerblom M-L, Sjöström S. Partiell sjukskrivning, arbete och livssituation: en utvärdering med genusperspektiv [Partial sick leave, work and lifesituation: evaluation with genderperspective]. Luleå (Sweden): Centrum för utbildning och forskning inom samhällsvetenskap, CUFS, Luleå tekniska universitet; 2001.

22. Sykefravaerstilfeller 1 kvartal 2003-2008-fylke og kjønn: totalt, gradert og aktiv sykemelding [Sickness absence statistics 1 quarter 2003-2008 — region and gender: full, partial and active sick leave] [Internet]. NAV [The Norwegian Labour and Welfare Administration]. Available at: http://www.nav. no/85962.cms.

23. Beskaeftigelsesministeriet. Analyse af sygefraværet [Analysis of sickness absence] [Internet]. Copenhagen: Beskaeftigelsesministeriet; 2008 [cited 9 June 2008]. Available at: http://www. bm.dk/graphics/dokumenter/temaer/sygefravaer/sygefravaer. pdf.

24. Arbejdsmarkedsstyrelsen. Jobindsats [Internet]. Copenhagen: Arbejdsmarkedsstyrelsen [cited 10 July 2008]. Available at: http://www.jobindsats.dk.

25. Damgaard B, Boll J. Opfølgning på sygedagpenge, del I: kommuners, lægers og virksomheders erfaringer med de nye regler [Follow-up of sickness benefits, part I: municipalities', physicians' and employers' experiences from the new regulations.] [Internet]. Copenhagen: Socialforskningsinstitute; 2007 [cited 9 June 2008]. SFI 2007, 1. Available at: http://www.sfi. dk/graphics/SFI/Pdf/Rapporter/2007/0701 Opfoelgning paa sygedagpenge1.pdf.

26. The Social Insurance Institution of Finland. Osasairairauspäivärahaa maksettu vuoden 2007 alusta: tilastotiedote 4.9.2007 [Partial sickness benefit available from the beginning of the year 2007: Kela statistics 4 September 2007] [Internet]. Helsinki: Social Insurance Institution of Finland [cited 1 November 2007]. Available at: http:// www.kela.fi/it/kelasto/kelasto.nsf/(WWWAllDocsById)/ 7F8C06C6F2626470C225738B00424E21/\$file/2 040907. pdf.

27. Lidwall U. Försäkringskassan och arbetslivsinriktad rehabilitering_aktiva åtgärder och återgång i arbete [The Swedish Social Insurance Agency and work-targeted rehabilitationactive measures and return to work] [Internet]. Stockholm: Försäkringsverket; 2006 [cited 9 June 2008]. RFV analyserar 2006, 10. Available at: http://forsakringskassan.se/filer/publikationer/pdf/ana0610.pdf.

28. Scheel IB, Hagen KB, Herrin J, Carling C, Oxman AD. Blind faith?: the effects of promoting active sick leave for back pain patients. Spine. 2002;27(23):2734-40.

29. Kann IC, Brage S. Endringer i fastlegenes sykmeldingspraksis konsekvenser for de sykmeldtes arbeidstilknytning og behov for trygdeytelser [Changes in physicians' sick listing practices: Consequences for the sick-listed subjects' relation to work and need for benefits] [Internet]. NAV; 2007 [cited 9 June 2008]. NAV-rapport, 3. Available at: $\underline{w w w . n a v . n o / b i n a r y ? i d=805416}$ $669 \&$ download=true.

30. Marnetoft S-U, Selander J, Bergroth A, Ekholm J. Factors associated with successful vocational rehabilitation in a Swedish rural area. J Rehabil Med. 2001;33:71-8.

31. Scheel I, Hagen K, Oxman A. Active sick leave for patients with back pain: all the players onside, but still no action. Spine. 2002;27(6):654-59.

32. van der Capellen C. Attityder till deltidssjukskrivning [Attitudes towards partial sick leave] [Internet]. Riksförsäkringskassan; 2004 [cited 2008 9.6]. RFV analyserar, 13. Available at: http://www.fk.se/filer/publikationer/pdf/ana0413.pdf.

33. Eklund M, Ossowicki M. Sjukskriven i onödan? [Unnecessary sick-listing?] [Internet]. Försäkringskassan; 2005. Försäkringskassan analyserar, 5 [cited 9 June 2008]. Available at: http:// www.forsakringskassan.se/filer/publikationer/pdf/ana0505. pdf.

34. Vuorinen H, Kivistö S, Joensuu M, Jahkola A, Virta L, Klaukka T. Miten osasairauspäiväraha on lähtenyt liikkeelle? [How has the partial sickness benefit been initiated in practice?]. Työterveyslääkäri. 2007:(4):92-5.

35. Arrelöv B. Sjukvården har möjlighet att påverka sjukskrivningarna [Healthcare has opportunities to affect sick listing] Läkartidningen. 2007;104(39):2788-91.

36. Varonen H, Kivistö S, Jahkola A, Virta L, Klaukka T. Työterveyslääkäreillä valmius hyödyntää osasairauspäivärahauudistusta. [Occupational physicians are set to utilize partial sickness benefit]. Suomen Lääkärilehti. 2007;62(45):4242-3.

37. Scheel IB, Hagen KB, Herrin J, Oxman AD. A call for action: a randomized controlled trial of two strategies to implement active sick leave for patients with low back pain. Spine. 2002;27(6):561-6.

38. Wahlström R, Alexanderson K. Physicians' sick listing practices. Scand J Public Health. 2004;32(suppl 63):222-55. 
39. Arrelöv B, Borgquist L, Ljungberg D, Svärdsudd K. Do GPs sick-list patients to a lesser extent than other physician categories? A population-based study. Fam Pract. 2001;18(4):3938.

40. Löfgren A, Hagberg J, Arrelöv B, Ponzer S, Alexanderson K. Frequency and nature of problems associated with sickness certification tasks: a cross-sectional questionnaire study of 5455 physicians. Scand J Prim Health Care. 2007;25:178-85.

41. Arrelöv B, Alexanderson K, Hagberg J, Löfgren A, Nilsson G, Ponzer S. Dealing with sickness certification-a survey of problems and strategies among general practitioners and orthopaedic surgeons. BMC Public Health. 2007;7(273).

42. Söderberg E, Alexanderson K. Sickness certificates as a basis for decisions regarding entitlement to sickness insurance benefits. Scand J Public Health. 2005;33:314-20.

43. Rae D. How to reduce sickness absences in Sweden: lessons from international experience. Paris: Organization for Economic Co-operation and Development (OECD); 2005 [cited 11 July 2008]. Economics department working papers, 442. Available at: http://lysander.sourceoecd.org/vl=1933224/cl=28/ nw=1/rpsv/workingpapers/18151973/wp 5lgmktrf2834.htm.

44. Martimo K-P, Kaila-Kangas L, Kausto J, Takala E-P, Ketola R, Riihimäki H, et al. Effectiveness of early part-time sick leave in musculoskeletal disorders. BMC Musculoskelet Disord. 2008:9:23.

45. Young AE, Wasiak R, Roessler RT, McPherson KM, Anema JR, van Poppel MNM. Return-to-work outcomes following work disability: stakeholder motivations, interests and concerns. J Occup Rehabil. 2005;15(4):543-56.

Received for publication: 16 November 2007

\section{Appendix I}

\section{Full sickness benefits (salaried employees) and government policies for sickness absence management in four Nordic countries (taken from references 1-7, listed below).}

\begin{tabular}{|c|c|c|c|c|}
\hline & Sweden & Norway & Denmark & Finland \\
\hline $\begin{array}{l}\text { Medical certificate } \\
\text { needed }\end{array}$ & From day 8 & $\begin{array}{l}\text { From day } 4 \text { (employee may } \\
\text { give notice of incapacity } \\
\text { for up to } 3 \text { days, a total of } \\
12 \text { days a year); according } \\
\text { to the Inclusive Workplace } \\
\text { Agreement, from day } 9 \text { (em- } \\
\text { ployee may give notice of inca- } \\
\text { pacity for up to } 8 \text { days, a total } \\
\text { of } 24 \text { days a year) }\end{array}$ & $\begin{array}{l}\text { From day } 4 \text { (if the benefit is paid by } \\
\text { the local authorities, a medical bul- } \\
\text { letin must be introduced no later than } \\
1 \text { week from the beginning of the sick } \\
\text { leave or } 1 \text { week after the last employer } \\
\text { payment) }\end{array}$ & $\begin{array}{l}\text { From day } 1 \text { to } 4 \text { (depend- } \\
\text { ing on collective or local } \\
\text { agreements) }\end{array}$ \\
\hline \multirow[t]{2}{*}{ Qualifying period } & $\begin{array}{l}\text { No work period or qualify- } \\
\text { ing period }\end{array}$ & 4 weeks of work & $\begin{array}{l}\text { Benefits paid by the employer: mini- } \\
\text { mum work period of } 74 \text { hours during } \\
\text { the } 8 \text { weeks preceding the sickness }\end{array}$ & $\begin{array}{l}\text { No work period or qualifying } \\
\text { period }\end{array}$ \\
\hline & & & $\begin{array}{l}\text { Benefits paid by the municipality: } \\
\text { minimum work period of } 120 \text { hours in } \\
\text { the } 13 \text { weeks preceding the illness }\end{array}$ & \\
\hline Waiting period & 1 day & 0 days & 0 days & 0 days \\
\hline Employer period & 13 days & 16 days & 15 days & $1+9$ days \\
\hline $\begin{array}{l}\text { Amount of benefit as } \\
\text { percentage of earned } \\
\text { income }\end{array}$ & $80 \%$ & $100 \%$ & $100 \%$ & $70 \%$ \\
\hline Length of payment & $\begin{array}{l}364 \text { days in } 15 \text { months (an } \\
\text { extension of } 550 \text { days is } \\
\text { possible; in certain medi- } \\
\text { cal cases the period can } \\
\text { even be longer) since } 1 \\
\text { July } 2008\end{array}$ & 52 calendar weeks in 3 years & $\begin{array}{l}52 \text { calendar weeks in } 18 \text { months (a } \\
\text { longer period in certain cases, eg, for a } \\
\text { re-education or rehabilitation process) }\end{array}$ & $\begin{array}{l}300 \text { days (excluding } \\
\text { Sundays) in } 2 \text { years (per } \\
\text { same illness) }\end{array}$ \\
\hline $\begin{array}{l}\text { Government } \\
\text { policies regarding } \\
\text { sickness absence } \\
\text { management }\end{array}$ & $\begin{array}{l}\text { Sickness absence rate } \\
\left(3.6 \% \text { in 2005) }{ }^{a} \text {, highest in }\right. \\
\text { European comparison but } \\
\text { decreasing recently }\end{array}$ & $\begin{array}{l}\text { Sickness absence rate }(3.2 \% \\
\text { in 2005) }{ }^{\text {a }} \text {, decreasing recently }\end{array}$ & $\begin{array}{l}\text { Sickness absence rate }(1.8 \% \text { in } \\
2005)^{\text {a }} \text {, slowly increasing (a national } \\
\text { goal has been set of reducing sickness } \\
\text { absence by } 20 \% \text { by } 2015)\end{array}$ & $\begin{array}{l}\text { Sickness absence rate }(2.5 \% \\
\text { in } 2005)^{\text {a }} \text {, slowly increasing } \\
\text { (a national public health pro- } \\
\text { gram carried out in } 2003- \\
2007 \text { set a target of reducing } \\
\text { sickness absence by } 15 \% \\
\text { between } 2002 \text { and } 2007 \text { ) }\end{array}$ \\
\hline
\end{tabular}


Appendix I continued.

\begin{tabular}{|c|c|c|c|c|}
\hline & Sweden & Norway & Denmark & Finland \\
\hline $\begin{array}{l}\text { Government policies } \\
\text { regarding sickness } \\
\text { absence manage- } \\
\text { ment (continued) }\end{array}$ & $\begin{array}{l}\text { Special attention has been } \\
\text { paid to bringing down the } \\
\text { rate of long-term sickness } \\
\text { absence; the government's } \\
\text { action program (2001) is } \\
\text { aimed at (i) improving the } \\
\text { work environment (particu- } \\
\text { lar focus on women), (ii) } \\
\text { increasing the liability of } \\
\text { employers, (iii) reforming } \\
\text { the administration of the } \\
\text { social insurance system, } \\
\text { and (iv) facilitating return } \\
\text { to work after sickness; the } \\
\text { administration of the so- } \\
\text { cial insurance system was } \\
\text { reformed in 2003-2004 } \\
\text { in order to rationalize the } \\
\text { methods in processing the } \\
\text { cases and restricting the } \\
\text { liberal granting of benefits; } \\
\text { partial sick leave is to be } \\
\text { established as a first choice } \\
\text { for sick-listing and modi- } \\
\text { fied work to be offered to } \\
\text { the employee } \\
\text { In } 2006 \text {, the responsi- } \\
\text { bility of rehabilitation } \\
\text { assessments shifted } \\
\text { from employers to case } \\
\text { managers in the Swedish } \\
\text { Social Insurance Agency } \\
\text { (Försäkringskassan); em- } \\
\text { ployers are still account- } \\
\text { able for the rehabilitation } \\
\text { measures taken at the } \\
\text { workplace to promote } \\
\text { return to work; the occupa- } \\
\text { tional health care system is } \\
\text { being reformed }\end{array}$ & $\begin{array}{l}\text { An agreement on "a more } \\
\text { inclusive workplace" was } \\
\text { signed in 2001; it is aimed at } \\
\text { reducing the use of sickness } \\
\text { and disability benefits, making } \\
\text { more efficient use of remain- } \\
\text { ing work ability (strengthened } \\
\text { use of partial sick leave and } \\
\text { active sick leave) and improv- } \\
\text { ing cooperation between } \\
\text { employers and the National } \\
\text { Insurance Service } \\
\text { Employers are responsible } \\
\text { for the follow-up of sickness } \\
\text { absence and return to work; } \\
\text { since } 2005 \text {, employers and } \\
\text { employees have been obliged } \\
\text { to prepare (together) a plan for } \\
\text { return to work within } 6 \text { weeks } \\
\text { of sick leave; general practitio- } \\
\text { ners are encouraged to moti- } \\
\text { vate patients to keep in touch } \\
\text { with their workplace } \\
\text { In } 2007 \text {, the regulations on the } \\
\text { follow-up of sickness absence } \\
\text { were tightened; the course } \\
\text { of sickness absence is as- } \\
\text { sessed at } 6 \text {, } 8 \text { and } 12 \text { weeks, } \\
6 \text { months, and } 1 \text { year after the } \\
\text { beginning of the sick leave } \\
\text { On } 1 \text { September } 2008 \text {, medical } \\
\text { certificate reform was enforced } \\
\text { to enable better communi- } \\
\text { cation between physicians, } \\
\text { patients, and employers in } \\
\text { modifying worktasks when } \\
\text { sick leave is not needed, but } \\
\text { the work ability of an employee } \\
\text { is reduced }\end{array}$ & $\begin{array}{l}\text { Municipalities are responsible for the } \\
\text { financing and administration of sick- } \\
\text { ness benefits and other social welfare } \\
\text { transfer payments, such as vocational } \\
\text { rehabilitation and disability benefits } \\
\text { Amendments to the law on sickness } \\
\text { benefits (2005) are aimed at system- } \\
\text { izing and harmonizing the diverse } \\
\text { practices in different municipalities; } \\
\text { the following practical measures in- } \\
\text { clude: (i) grouping those sick-listed } \\
\text { into three groups according to the risk } \\
\text { of losing contact with the labor market, } \\
\text { (ii) closer follow-up of employees in } \\
\text { these categories by case managers in } \\
\text { the municipalities (obligatory follow-up } \\
\text { plan), (iii) increased use of partial sick } \\
\text { leave, adjustments of worktasks and } \\
\text { better coordination between authorities } \\
\text { encouraged } \\
\text { Medical, social, and vocational infor- } \\
\text { mation used in the follow-up assess- } \\
\text { ments (done within } 8 \text { weeks of the } \\
\text { beginning of a sick leave and, from } \\
\text { then on, every } 2 \text { months); employers } \\
\text { not responsible for managing sick- } \\
\text { ness absence; employees can be given } \\
\text { notice because of sickness and during } \\
\text { sickness absence }\end{array}$ & $\begin{array}{l}\text { Sickness insurance com- } \\
\text { pensates for loss of income } \\
\text { (during sickness, preg- } \\
\text { nancy, or child's sickness) } \\
\text { and expenses of medical } \\
\text { treatment (either in the } \\
\text { public or private sector); the } \\
\text { general compensation level } \\
\text { of health-related benefits is } \\
\text { lower than in other Nordic } \\
\text { countries, and the control of } \\
\text { sick leaves and the granting } \\
\text { of sickness benefits is rela- } \\
\text { tively strict } \\
\text { Until recent years, relatively } \\
\text { few measures have been } \\
\text { taken that are aimed at partly } \\
\text { incapacitated employees; a } \\
\text { partial sickness benefit was } \\
\text { launched in } 2007 \text { with more } \\
\text { strict terms than in the other } \\
\text { Nordic countries; however, } \\
\text { these terms are currently be- } \\
\text { ing reconsidered } \\
\text { The employers' share of } \\
\text { financing sickness absence } \\
\text { and disability pensions is } \\
\text { large; obligatory occupa- } \\
\text { tional health care is respon- } \\
\text { sible for health promotion } \\
\text { and preventive measures } \\
\text { at workplaces; employee } \\
\text { pension companies actively } \\
\text { offer rehabilitation measures } \\
\text { in supporting employees' } \\
\text { continuing in and returning } \\
\text { to work }\end{array}$ \\
\hline
\end{tabular}

a Of all those employed, the percentage absent due to illness for at least the whole reference week of the Labour Force Survey in 2005 (5).

\section{References}

1. Försäkringskassan. Nordiska strategier för att begränsa sjukfrånvaron [Strategies of the Nordic countries for limiting sickness absence] [Internet]. Försäkringskassan; 2008. Socialförsäkringsrapport, 1 [cited 9 June 2008]. Available at: http://www. forsakringskassan.se/filer/publikationer/pdf/sfr0801.pdf.

2. Hytti H. Disability policies and employment: Finland compared with the other Nordic countries [Internet]. Helsinki: The Social Insurance Institution of Finland, Research Department; 2008 [cited 10 June 2008]. Social Security and Health Research: Working Papers, 62. Available at: http://www.kela. fi/in/internet/liite.nsf/NET/280508093718EK/\$File/Selosteita62.pdf?openElement.

3. Hytti H. The Finnish employment and income security models in a Nordic comparison [Internet]. Helsinki: Social Insurance Institution of Finland, Research Department; 2006 [cited 2008 9.6]. Social Security and Health Research Working papers, 52. Available at: http://www.kela.fi/in/internet/liite.nsf/NET/ 100506142717EK/\$File/Seloste52netti.pdf?OpenElement.

4. European Commission. MISSOC tables 2007: comparative tables on social protection in the 27 member states of the European Union, in the European economic area and in Switzerland-situation on 1 January 2007. Brussels: European Commission [cited 2 May 2008]. Comparative tables, parts 1, 6 and 8. Available at: http://ec.europa.eu/employment social/ spsi/missoc tables en.htm.

5. Nordic Social-Statistical Committee. Social protection in the Nordic countries, 2005: scope, expenditure and financing [Internet]. Copenhagen: Nordic Social-Statistical Committee; 2007 [cited 2 May 2008]. Available at: http://nososco-eng. nom-nos.dk/.

6. Försäkringskassan. Tidsbegränsning av sjukpenning [Time restricted sickness benefit] [Internet]. Försäkringskassan [cited 7 July 2008]. Available at: http://forsakringskassan.se/privatpers/sjuk/nya_regler_080701/tidsbeg_sjp/index.php.

7. Norwegian Labour and Welfare Administration (NAV). Sykmelding? eller kanskje ikke? [Sick leave? or perhaps not?] [Internet]. NAV [cited 10 September 2008]. Available from: http://nav.no/87520.cms. 